\title{
Selected Pacific Northwest Rangeland and Weed Plants as Hosts of Pratylenchus neglectus and $P$. thornei
}

Richard W. Smiley, Professor, Guiping Yan, Research Associate, and Jennifer A. Gourlie, Faculty Research Assistant, Oregon State University, Columbia Basin Agricultural Research Center, P.O. Box 370, Pendleton, OR 97801

\begin{abstract}
Smiley, R. W., Yan, G. P., and Gourlie, J. A. 2014. Selected Pacific Northwest rangeland and weed plants as hosts of Pratylenchus neglectus and P. thornei. Plant Dis. 98:1333-1340.

Eighteen rangeland plants and 16 weed species were assayed in the greenhouse for efficiency as hosts of Pratylenchus neglectus and $P$. thornei. Hosting ability ratings were assigned using the ratio of final versus initial nematode density and by comparing the final nematode density to that of susceptible wheat controls. Good hosts of both Pratylenchus spp. included thickspike bluegrass 'Critana', smooth brome 'Manchar', seven wheatgrasses, and jointed goatgrass. Good hosts of $P$. neglectus but not $P$. thornei included two hairy vetches, western wheatgrass 'Rosana', big bluegrass 'Sherman', tall wheatgrass

'Alkar', green foxtail, kochia, large crabgrass, palmer amaranth, redroot pigweed, tumble mustard, and wild oat. Good hosts of $P$. thornei but not $P$. neglectus included hard fescue 'Durar', sheep fescue 'Blacksheep', downy brome, and rattail fescue. Poor or minor hosts of both Pratylenchus spp. included two alfalfas, dandelion, horseweed, lambsquarters, prostrate spurge, and Russian thistle. These assays will provide guidance for transitioning rangeland into crop production and for understanding the role of weeds on densities of Pratylenchus spp. in wheat-production systems.
\end{abstract}

Agricultural fields in low-precipitation regions of the Pacific Northwest (PNW; southern Idaho, eastern Oregon, and eastern Washington) are frequently infested by one or more species of Pratylenchus (12,31,38). Approximately $90 \%$ of rainfed production systems are infested by $P$. neglectus (Rensch) Filipjev Schuurmanns \& Stekhoven, by $P$. thornei Sher \& Allen, or by mixtures of these two species. The occurrence of $P$. thornei is more geographically restricted than for P. neglectus. Yields of rainfed wheat (Triticum aestivum L.) in low-precipitation environments $(<400 \mathrm{~mm}$ annually) are often inversely correlated with preplant densities of these nematodes $(29,35,36)$. Both species have reduced grain yields by as much as $60 \%$ in PNW rainfed wheat $(29,35,36)$ and are estimated to reduce profitability of wheat production in the PNW by at least $\$ 51$ million annually (28).

More than one million hectares of former wheat-producing land on 10,321 farms in Idaho, Oregon, and Washington are currently maintained under contracts to the USDA Natural Resource Conservation Service's Conservation Reserve Program (USDA-NRCSCRP) (46). Ten-year CRP contracts require the planting of mixtures of three to five native grasses and one or more forbs or legumes adapted to local environments and best suited to wildlife in that area. Species and cultivars meeting the minimal requirement are specified in the contract. Upon expiration of a contract, the producer may continue to maintain the land as rangeland without federal funding, return the land to crop production, or negotiate another CRP contract. Land retired from a CRP contract in the inland PNW is mostly returned immediately to wheat production. In the inland PNW during the next 5 years (2014 to 2019), CRP contracts will expire for about 365,000 ha of land at rates varying from 60,000 to $88,000 \mathrm{ha}$ /year (46).

$P$. neglectus is commonly associated with forage grasses as well as cereals $(3,23)$, and many grasses and legumes have been evaluated for their hosting efficiency for $P$. neglectus $(7-9,11,25,43)$. Densities of $P$. neglectus well above the threshold for causing yield

Corresponding author: R. Smiley, E-mail: richard.smiley@ oregonstate.edu

Accepted for publication 4 April 2014.

http//dx.doi.org/10.1094/PDIS-12-13-1295-RE

(C) 2014 The American Phytopathological Society reduction in wheat have been detected in spring wheat planted into former CRP rangeland (33). However, potential risks associated with nematode damage after growing most CRP species and cultivars recommended for the PNW (49) are unknown. Wheat producers and their advisors in the PNW have requested guidance on procedures that will result in the lowest economic risk for returning CRP rangeland back into crop production. They inquire as to whether land should be fallowed for a prolonged interval or planted directly to a specific wheat cultivar or to another crop species. Development of guidelines recognizing the potential importance of Pratylenchus spp. requires that rangeland plant species be screened to determine potential differences in hosting abilities for $P$. neglectus and/or P. thornei.

Population densities of $P$. neglectus and/or P. thornei are also often maintained at high levels where volunteer cereals or weeds are allowed to grow at any time within or between planted crops in PNW wheat production systems $(28,31)$. The role of specific weed species as bridging hosts for Pratylenchus spp. in the PNW remains unknown. Pratylenchus spp. are known to invade roots of selected monocot and broadleaf weeds $(4,15,51,52)$, but assays of hosting abilities performed thus far have been with weed species occurring in other countries or in regions with climates that differ from those in the PNW.

The objective of this research was to characterize selected rangeland and weed species and cultivars of potential importance to PNW wheat producers for their ability to serve as hosts of $P$. neglectus and P. thornei.

\section{Materials and Methods}

Eighteen rangeland plants and 16 weed species were assayed as two separate plant groups (monocots and dicots) and separately for the two nematode species: $P$. neglectus and $P$. thornei. The four assays were performed twice during successive years in a greenhouse at Oregon State University's Columbia Basin Agricultural Research Center, Pendleton.

Test plants and controls. Rangeland plant entries (Table 1) were selected based upon multiple climate-specific planting guides that provide recommendations for establishing rangelands that qualify for funding under Conservation Practices CP1 and CP2 of the USDA-NRCS-CRP (49). Entries included beardless wheatgrass (Pseudoroegneria spicata (Pursh) Á. Löve), crested wheatgrasses (Agropyron cristatum (L.) Gaertn., Agropyron desertorum (Fisch. 
Ex Link) Schult., and A. cristatum $\times A$. desertorum), Siberian wheatgrass (Agropyron fragile (Roth) Candargy), intermediate wheatgrass (Elytrigia intermedia (Host) Nevski), tall wheatgrass (Elytrigia elongata (Host) Nevski), thickspike wheatgrass (Elymus lanceolatus (Scribn. \& J.G. Sm.) Gould), western wheatgrass (Pascopyrum smithii (Rydb.) Á. Love), Snake River wheatgrass (Elymus wawawaiensis J. Carlson \& Barkworth), hard fescue (Festuca brevipila Tracey), sheep fescue (Festuca ovina L.), big bluegrass (Poa secunda J. Presl. subsp. nevadensis (Scribn.) Soreng), smooth brome (Bromus inermis Leyss.), two subspecies of alfalfa (Medicago sativa (L.) subsp. sativa (L.) and Medicago sativa (L.) subsp. falcata (L.) Archang.), and two hairy vetches (Vicia villosa Roth). Weed entries (Table 1) common to the PNW (54) included species in six plant families: Amaranthaceae, Asteraceae, Brassicaceae, Chenopodiaceae, Euphorbiaceae, and Poaceae.

Controls included inoculated unplanted soil, noninoculated unplanted soil, and susceptible wheat controls composed of two Pratylenchus-susceptible wheat cultivars ('Louise' and 'Otis'; 27,41). The wheat controls were used to make direct comparisons with unknown plant entries and the unplanted inoculated soil control. The inoculated unplanted soil control was included to allow for evaluation of inoculum survival in the absence of a host plant, and for comparisons of final nematode densities in planted versus unplanted soil. The noninoculated unplanted soil control served to determine whether nematodes were transferred from one assay pot to another during the watering process.

Assay procedure. Assays were conducted in a manner similar to that described for previous assays of wheat and barley $(27,41)$. An Adkins fine sandy loam was passed through a 4-mm screen, lightly moistened, incubated for several days, and treated in an oven at $90^{\circ} \mathrm{C}$ for 2 days to kill active nematodes. Soil was then stored in closed bins to allow for microbial and chemical stabilization.

Monocotyledonous plant species were assayed in cones measuring $3.8 \mathrm{~cm}$ top diameter $\times 20 \mathrm{~cm}$ tall (Ray Leach $\mathrm{S} 10$ Super Conetainers; Stuewe and Sons, Inc., Corvallis, OR). The wheat and unplanted soil controls were also assayed in the S10 cones. Individual cones were filled with $160 \mathrm{~g}$ of soil after cotton balls were placed at the bottom of each cone to retain soil that would otherwise escape through the holes at the bottom. Cones were held vertical in RL98 support trays which in turn were placed within FlowTSM flow trays (Stuewe and Sons) to facilitate capillary watering through subirrigation.

Dicotyledonous plant entries were assayed in the same manner except that they were planted into $600 \mathrm{~g}$ of soil in larger cones measuring $6.4 \mathrm{~cm}$ top diameter $\times 25.4 \mathrm{~cm}$ tall (D40 Deepots; Stuewe and Sons). These cones were supported by D20T Support Trays capable of holding 20 Deepots. For these assays, the unplanted soil and wheat controls were also planted into the D40 Deepots.

Assays were performed as four separate blocks, each with its own controls: monocots inoculated with either $P$. neglectus or $P$. thornei, or dicots inoculated with either P. neglectus or P. thornei. Initiation of each assay was offset by a 1- to 2-week interval to assure availability of nematode inoculum and labor for each phase of each assay. For individual assays, one seed of each plant species was placed into each of eight pots (replicates). Each plant species and cultivar was compared to the controls that were also replicated and arranged with other entries as randomized complete blocks within each of the four assays. Multiple replicates were placed into individual flow trays. Assays involving P. neglectus or P. thornei

Table 1. Plant entries assayed for hosting efficiencies of Pratylenchus neglectus and P. thornei

\begin{tabular}{|c|c|c|c|c|}
\hline Plant group & Plant family & Genus and species & Common name & Cultivar \\
\hline Control & Poaceae & Triticum aestivum & Wheat ${ }^{\mathrm{y}}$ & Louise \\
\hline Control & Poaceae & Triticum aestivum & Wheat ${ }^{\mathrm{y}}$ & Otis \\
\hline Range & Fabaceae & Medicago sativa subsp. falcata & Alfalfa ${ }^{z}$ & Don \\
\hline Range & Fabaceae & Medicago sativa subsp. sativa & Alfalfa ${ }^{z}$ & Ladak-65 \\
\hline Range & Fabaceae & Vicia villosa & Hairy vetch ${ }^{\mathrm{z}}$ & Purple Bounty \\
\hline Range & Fabaceae & Vicia villosa & Hairy vetch ${ }^{z}$ & Purple Prosperity \\
\hline Range & Poaceae & Agropyron cristatum & Crested wheatgrass & Fairway \\
\hline Range & Poaceae & A. cristatum $\times$ A. desertorum & Crested wheatgrass & Hycrest \\
\hline Range & Poaceae & Agropyron desertorum & Standard crested wheatgrass & Nordan \\
\hline Range & Poaceae & Agropyron fragile & Siberian wheatgrass & Vavilov \\
\hline Range & Poaceae & Bromus inermis & Smooth brome & Manchar \\
\hline Range & Poaceae & Elymus wawawaiensis & Snake River wheatgrass & Secar \\
\hline Range & Poaceae & Elymus lanceolatus & Thickspike wheatgrass & Critana \\
\hline Range & Poaceae & Elytrigia elongata & Tall wheatgrass & Alkar \\
\hline Range & Poaceae & Elytrigia intermedia & Intermediate wheatgrass & Greenar \\
\hline Range & Poaceae & Festuca ovina & Sheep fescue & Blacksheep \\
\hline Range & Poaceae & Festuca brevipila & Hard fescue & Durar \\
\hline Range & Poaceae & Pascopyrum smithii & Western wheatgrass & Rosana \\
\hline Range & Poaceae & Poa secunda & Big bluegrass & Sherman \\
\hline Range & Poaceae & Pseudoroegneria spicata & Beardless wheatgrass & Whitmar \\
\hline Weed & Amaranthacae & Amaranthus palmeri & Palmer amaranth & $\ldots$ \\
\hline Weed & Amaranthacae & Amaranthus retroflexus & Redroot pigweed & $\ldots$ \\
\hline Weed & Asteracae & Conyza canadensis & Horseweed & $\ldots$ \\
\hline Weed & Asteracae & Taraxacum officinale & Dandelion & $\ldots$ \\
\hline Weed & Brassicaceae & Sisymbrium altissimum & Tumble mustard & $\ldots$ \\
\hline Weed & Chenopodiaceae & Bassia scoparia & Kochia & $\ldots$ \\
\hline Weed & Chenopodiaceae & Chenopodium album & Common lambsquarters & $\ldots$ \\
\hline Weed & Chenopodiaceae & Salsola tragus & Russian thistle & $\ldots$ \\
\hline Weed & Euphorbiaceae & Euphorbia humistrata & Prostrate spurge & $\ldots$ \\
\hline Weed & Poaceae & Aegilops cylindrica & Jointed goatgrass & $\ldots$ \\
\hline Weed & Poaceae & Avena fatua & Wild oat & $\ldots$ \\
\hline Weed & Poaceae & Bromus tectorum & Downy brome & $\ldots$ \\
\hline Weed & Poaceae & Digitaria sanguinalis & Large crabgrass & $\ldots$ \\
\hline Weed & Poaceae & Poa bulbosa & Bulbous bluegrass (apomectic) & $\ldots$ \\
\hline Weed & Poaceae & Setaria viridis & Green foxtail & $\ldots$ \\
\hline Weed & Poaceae & Vulpia myuros & Rattail fescue & $\ldots$ \\
\hline
\end{tabular}

y Pacific Northwest wheat control cultivars that exhibited susceptible reactions to P. neglectus and $P$. thornei in previous experiments.

${ }^{z}$ Alfalfa and hairy vetch cultivars are legumes included in many Pacific Northwest rangeland plantings but are also grown as forage or green manure crops in irrigated agriculture and in higher precipitation zones of the Pacific Northwest. 
were placed into different flow trays. After planting, the soil was subirrigated to moisten the soil by capillary action. This was accomplished by placing water in the flow tray to a level just covering the holes at the bottoms of all cones. Excess water was siphoned from the trays 1 day after watering was initiated. This process was repeated each time the soil surface in most cones appeared to be dry, for which the timing varied as plants became established and matured.

When a seedling failed to emerge, the cone was replanted and marked for an appropriate set-back of timings for inoculation and harvest. Cones of soil were removed from the assay if seedlings failed to become established after three plantings.

Plant nutrients were supplied 3 weeks after planting by inserting slow-release fertilizer cylinders $(5 \mathrm{~mm}$ diameter $\times 50 \mathrm{~mm}$ long; $13 \% \mathrm{~N}, 4 \% \mathrm{P}_{2} \mathrm{O}_{5}, 5 \% \mathrm{~K}_{2} \mathrm{O}$; Jobe's Fertilizer Spikes, Easy Gardener, Inc., Waco, TX) into each cone. One cylinder was placed into smaller cones used to assay monocots, and two cylinders were placed into cones used to assay dicots. Additional fertilizer was supplied with the irrigation water during the latter stages of incubation, using Miracle-Gro All-Purpose Plant Food (15\% N, 30\% $\mathrm{P}_{2} \mathrm{O}_{5}, 15 \% \mathrm{~K}_{2} \mathrm{O}$, plus micronutrients; Scotts Miracle-Gro Products, Marysville, $\mathrm{OH})$. Aphids were controlled by foliar applications of esfenvalerate (Bug-B-Gon Multi-purpose Insect Killer, Ortho, Inc., Columbus, $\mathrm{OH}$ ), and powdery mildew was controlled by foliar applications of triadimefon (Bayleton, Mobay Chemical Co., Kansas City, MO).

The four assays were performed during 2011 and were repeated during 2012, using the same seed lots and nematode parent cultures each year. Assays were conducted in a greenhouse maintained at about $22^{\circ} \mathrm{C}$, and with daylight supplemented by a 12 -h period using 1,000-watt high-pressure sodium horticultural lamps. During the second year, cones were hand watered from the top to avoid the potential for soil saturation that may have occurred with the bottom watering method used during 2011. During 2012, each pot was watered to a gravimetric content of about $0.25 \mathrm{~g} / \mathrm{g}$ as needed, and fertilizer was applied using the same sources and timing, except that the Miracle-Gro was applied with irrigation water applied to the soil surface.

Inoculum, inoculation, and extraction. $P$. neglectus and $P$. thornei were isolated from infested fields. Inoculum of $P$. neglectus was a composite of five individual cultures derived from populations at four Oregon locations (Adams: 45.7205, -118.6256; Imbler: 45.3750; -117.9455; Moro: 45.4852, -120.7126; and Union: 45.2955, -117.9494) and one Washington location (Lind: 47.0010, -118.5582). A single isolate of $P$. thorne $i$ was derived from a field near Adams, OR (45.7181, -118.6283). Single surface-sterilized adult females were placed onto sterilized carrot disks to establish pure cultures of each isolate (18). Cultures were incubated at $22^{\circ} \mathrm{C}$ for at least 3 months, and the species in each culture was identified using morphological and molecular methods $(13,55)$. Inoculum of each species was increased by transferring a small number of individuals from stock laboratory carrot cultures onto additional surface-sterilized carrot disks maintained individually in petri dishes under aseptic conditions in a laboratory incubator. Mature cultures were evaluated to assure nematode purity and vitality. Inocula for use in greenhouse assays were extracted by cutting the carrot disks into thin slices and floating the carrot pieces in distilled water in a petri dish. Nematodes were recovered using a $20-\mu \mathrm{m}$ sieve and were stored for short periods at $8^{\circ} \mathrm{C}$ before use.

Soil was inoculated approximately 2 weeks after planting, soon after seedling emergence. An aqueous suspension of nematodes was placed into small diameter holes made in the surface $2 \mathrm{~cm}$ of soil on either side of the seedling. Inoculum during 2011was applied as 2,700 P. neglectus or 2,900 P. thornei $/ \mathrm{kg}$ of soil for assays of monocots, and 2,014 P. neglectus or 2,128 P. thornei $/ \mathrm{kg}$ of soil for assays of dicots. During 2012, inoculum was applied as 2,500 P. neglectus or 2,594 P. thornei $/ \mathrm{kg}$ of soil for assays of monocots, and 2,317 P. neglectus or 2,017 P. thornei $/ \mathrm{kg}$ of soil for assays of dicots.

Experiments were terminated 16 and 12 weeks after inoculation during 2011 and 2012, respectively. Shoots were removed from plants, and the roots and soil from each cone were stored in a cold room until nematodes were extracted and counted. Soil and roots were finely chopped, and nematodes were extracted from soil and roots over a 48-h period using the Whitehead tray method (53). Nematodes were collected by wet sieving (U.S.A. Standard Testing Sieve No. $635 ; 20-\mu \mathrm{m}$ openings) and were quantified using a counting slide viewed under a dissecting microscope.

Reproductive factor and hosting ability rating. Reproductive factors $(R f ; 20)$ were calculated for each treatment by dividing the final nematode density $(P f)$ by the initial nematode inoculum density $(P i)$. Five hosting ability groups were designated to simplify interpretation of the data; nonhosts $(R f<0.1)(17)$, poor hosts $(R f=$ 0.1 to 0.9$)(17)$, minor hosts $(R f=1.0$ to 4.9$)$, good hosts $(R f=5.0$ to 9.9$)$, and very good hosts $(R f \geq 10)(5)$.

Statistical analysis. Nematode counts $(P f$, nematodes $/ \mathrm{kg}$ of soil) were normalized using the $\ln (x+1)$ transformation (24). Data for the four assays ( 2 plant family groups $\times 2$ Pratylenchus spp. inoculum) were analyzed separately each year using ANOVA. Main treatments were entry and replicates were blocks. ANOVA was performed using CoStat Statistical Software (CoStat version 6.400; CoHort Software, Minneapolis, MN). When treatment means were significant at $P<0.05$, means were separated using the Least Significant Difference (LSD) test. The LSD test was applied because numbers of replicates with established plants were less than eight for some plant entries, particularly during 2011 . The $R f$ values that had been calculated using nontransformed data were also analyzed separately by experiment and year. Means of $R f$ values and standard errors of the means were calculated and, when means were significant at $P<0.05$, they were separated using the LSD test.

\section{Results}

Very few Pratylenchus spp. (0 to 50 nematodes $/ \mathrm{kg}$ of soil; mean $=2.1$ ) were detected in soil that had not been inoculated (data not presented), indicating that little or no transfer of nematodes occurred in the irrigation water. Likewise, only a few containers revealed the presence of non-plant-parasitic nematode species at the end of each of the eight assays, indicating that few nematodes survived the heat treatment initially applied to soil.

Densities of Pratylenchus spp. declined dramatically in the absence of a host plant during the 16- and 12-week assay periods during 2011 and 2012, respectively. During 2011, the nematode density was 98 to $99 \%$ lower at the end than at the beginning of all four assays (Tables 2 and 3), indicating that assay conditions during 2011 were unfavorable to these nematodes in the absence of a host. During 2012, there were 80 to $84 \%$ fewer Pratylenchus spp. in unplanted, inoculated soils than were inoculated into soils for monocots (Table 4) and 61 to 69\% fewer Pratylenchus spp. than were inoculated into soils for dicots (Table 5), indicating a more favorable environment for nematode survival during 2012 than 2011 , as well as an incubation period that was $25 \%$ shorter, during which time nematode mortality may have occurred in the absence of a host.

Seedling emergence and plant establishment were more complete for all four assays during 2012 compared to 2011. In the assays of 20 monocots other than wheat against $P$. neglectus, plants were established successfully and soils were harvested from $68 \%$ of possible pots (108 of 160 pots) during 2011 (Table 2) and from 99\% of pots during 2012 (Table 4). For P. thornei, the successful culture of monocots was 58 and 100\% during 2011 (Table 2) and 2012 (Table 4), respectively. Likewise, success rates for assays of 13 dicots other than wheat against $P$. neglectus were $12 \%$ during 2011 (Table 3) and 85\% during 2012 (Table 5). For assays of dicots against $P$. thornei, rates of success were $19 \%$ during 2011 (Table 3) and 88\% during 2012 (Table 5). Growth and development of nearly all monocot and dicot entries were more normal during 2012 compared to 2011. While numbers of successful cultures during 2011 were limited for some plant entries, the data for successful cultures during 2011 served as important comparisons with results from the more robust experiment conducted during 2012. 
During 2011, only the assay of $P$. neglectus on monocots was deemed adequate for comparisons of susceptible wheat with other plant entries; $R f$ values for the wheat controls were 9.2 and 10.6 (Table 2). Other monocots that maintained the P. neglectus density $(R f>1.0)$ during 2011 were green foxtail (Setaria viridis (L.) P. Beauv.), large crabgrass (Digitaria sanguinalis (L.) Scop.), and wild oat (Avena fatua L.) (Table 2). Six of the range grasses and monocot weeds did not differ from the susceptible wheat controls when evaluated using log-transformed data: hard fescue 'Durar', western wheatgrass 'Rosana', green foxtail, large crabgrass, rattail fescue (Vulpia myuros (L.) C.C. Gmel.), and wild oat.

The other three assays during 2011 resulted in $R f$ values for the wheat controls ranging from 0.6 to 7.4 (Tables 2 and 3), indicating that conditions had been generally unfavorable for multiplication of these Pratylenchus spp. during 2011 and that the wheat controls in three assays were not conducive to high rates of Pratylenchus spp. multiplication. Although comparisons could not be made directly in those three assays, there were indications of potentially

Table 2. Multiplication rates and hosting abilities of Pratylenchus spp. for monocotyledonous rangeland and weed plants during 2011

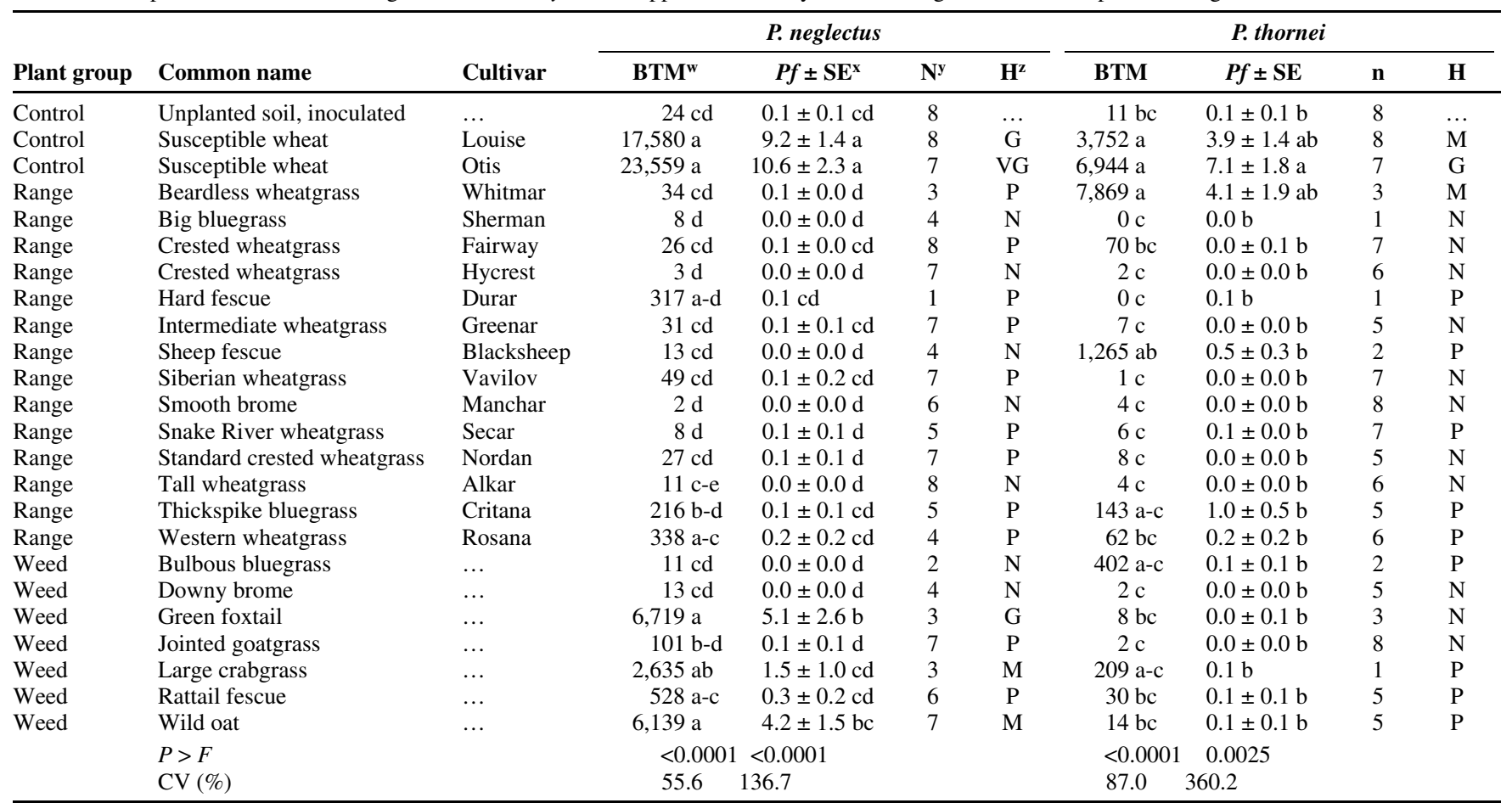

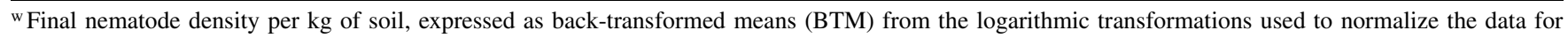
ANOVA. Means followed by the same letter did not differ significantly at $P<0.05$ as determined by Least Significant Difference. Assays were over $16-$ week incubation period.

${ }^{\mathrm{x}}$ Reproductive factor $(R f)$ and standard error of the mean (SE) calculated as the final nematode density $(P f)$ divided by the density of Pratylenchus initially added into soil ( $P i) ; P i$ rates were 2,700 P. neglectus $/ \mathrm{kg}$ of soil and 2,900 P. neglectus $/ \mathrm{kg}$ of soil.

$\mathrm{y}$ Number of observations included in the analysis; $\mathrm{n}<8 / \mathrm{year}$ indicates a failure of seedling establishment.

${ }^{\mathrm{z}}$ Hosting ability ratings; $\mathrm{N}=$ nonhost $(R f<0.1), \mathrm{P}=$ poor host $(R f=0.1$ to 0.9$), \mathrm{M}=$ minor host $(R f=1.0$ to 4.9$), \mathrm{G}=\operatorname{good}$ host $(R f=5.0$ to 9.9$), \mathrm{VG}=$ very good host $(R f \geq 10.0)$.

Table 3. Multiplication rates of Pratylenchus spp. on dicotyledonous rangeland and weed plants during 2011

\begin{tabular}{|c|c|c|c|c|c|c|c|c|c|c|}
\hline \multirow[b]{2}{*}{ Plant group } & \multirow[b]{2}{*}{ Common name } & \multirow[b]{2}{*}{ Cultivar } & \multicolumn{4}{|c|}{ P. neglectus } & \multicolumn{4}{|c|}{ P. thornei } \\
\hline & & & BTM $^{w}$ & $R f \pm \mathrm{SE}^{\mathrm{x}}$ & $\mathrm{N}^{\mathbf{y}}$ & $\mathbf{H}^{\mathbf{z}}$ & ВТМ & $R f \pm \mathrm{SE}$ & $\mathbf{n}$ & $\mathbf{H}$ \\
\hline Control & Unplanted soil, inoculated & & $43 \mathrm{~b}$ & $0.1 \pm 0.0$ & 8 & & $10 \mathrm{~cd}$ & $0.0 \pm 0.0 \mathrm{~b}$ & 8 & \\
\hline Control & Susceptible wheat & Louise & 8,829 a & $7.4 \pm 2.4$ & 5 & G & $1,622 \mathrm{a}$ & $0.6 \pm 0.2 b$ & 8 & $\mathrm{P}$ \\
\hline Control & Susceptible wheat & Otis & $4,485 \mathrm{a}$ & $4.7 \pm 1.9$ & 6 & $\mathrm{M}$ & $3,314 \mathrm{a}$ & $1.6 \pm 0.6 \mathrm{a}$ & 6 & M \\
\hline Range & Alfalfa & Don & & $\ldots$ & 0 & $\ldots$ & $128 \mathrm{a}-\mathrm{d}$ & $0.0 \mathrm{~b}$ & 1 & $\mathrm{~N}$ \\
\hline Range & Hairy vetch & Purple Bounty & $4,016 \mathrm{ab}$ & 1.5 & 1 & M & 304 a-e & $0.1 \pm 0.0 \mathrm{~b}$ & 2 & $\mathrm{P}$ \\
\hline Weed & Common lambsquarters & $\ldots$ & $\ldots$ & $\ldots$ & 0 & $\ldots$ & $0 \mathrm{~d}$ & $0.0 \pm 0.0 \mathrm{~b}$ & 2 & $\mathrm{~N}$ \\
\hline Weed & Dandelion & $\ldots$ & $\ldots$ & $\ldots$ & 0 & $\ldots$ & 399 a-c & $0.1 \pm 0.0 \mathrm{~b}$ & 2 & $\mathrm{P}$ \\
\hline Weed & Kochia & $\ldots$ & $407 \mathrm{~b}$ & $0.9 \pm 0.5$ & 7 & $\mathrm{P}$ & $20 \mathrm{~b}-\mathrm{d}$ & $0.0 \pm 0.0 \mathrm{~b}$ & 5 & $\mathrm{~N}$ \\
\hline Weed & Palmer amaranth & $\ldots$ & $26 \mathrm{~b}$ & $0.1 \pm 0.1$ & 2 & $\mathrm{P}$ & $183 \mathrm{a}-\mathrm{c}$ & $0.1 \pm 0.0 \mathrm{~b}$ & 2 & $\mathrm{P}$ \\
\hline Weed & Redroot pigweed & $\ldots$ & $\ldots$ & $\ldots$ & 0 & $\ldots$ & $6 \mathrm{~cd}$ & $0.0 \pm 0.0 \mathrm{~b}$ & 3 & $\mathrm{~N}$ \\
\hline \multirow[t]{3}{*}{ Weed } & Russian thistle & $\ldots$ & $1,547 \mathrm{ab}$ & $2.0 \pm 1.9$ & 2 & M & $439 a b$ & $0.2 \pm 0.1 \mathrm{~b}$ & 3 & $\mathrm{P}$ \\
\hline & $P>F$ & & 0.0084 & 0.2196 & & & 0.0056 & 0.0036 & & \\
\hline & $\mathrm{CV}(\%)$ & & 34.7 & 189.7 & & & 45.4 & 141.8 & & \\
\hline
\end{tabular}

${ }^{\mathrm{w}}$ Final nematode density per kg of soil, expressed as back-transformed means (BTM) from the logarithmic transformations used to normalize the data for ANOVA. Means followed by the same letter did not differ significantly at $P<0.05$ as determined by Least Significant Difference. Assays were over $16-$ week incubation period.

${ }^{\mathrm{x}}$ Reproductive factor $(R f)$ and standard error of the mean $(\mathrm{SE})$ calculated as the final nematode density (Pf) divided by the density of Pratylenchus initially added into soil (Pi); Pi rates were 2,014 P. neglectus $/ \mathrm{kg}$ of soil and 2,128 P. thornei/kg of soil.

${ }^{y}$ Number of observations included in the analysis; $\mathrm{n}<8 / \mathrm{year}$ indicates a failure of seedling establishment.

${ }^{\mathrm{z}}$ Hosting ability ratings; $\mathrm{N}=$ nonhost $(R f<0.1), \mathrm{P}=$ poor host $(R f=0.1$ to 0.9$), \mathrm{M}=\operatorname{minor}$ host $(R f=1.0$ to 4.9$), \mathrm{G}=\operatorname{good}$ host $(R f=5.0$ to 9.9$), \mathrm{VG}=$ very good host $(R f \geq 10.0)$. 
important rates of multiplication of $P$. thornei on beardless wheatgrass 'Whitmar', sheep fescue 'Blacksheep', thickspike bluegrass 'Critana', bulbous bluegrass (Poa bulbosa L.), and large crabgrass (Table 2), and of P. neglectus on hairy vetch 'Purple Bounty' and Russian thistle (Salsola tragus L.) (Table 3).
All four assays during 2012 produced $R f$ values greater than 10.0 for each of the susceptible controls (Tables 4 and 5). For P. neglectus during 2012, 15 of 20 monocot entries had log-transformed means and $R f$ values that were significantly comparable $(P>0.05)$ to at least one of the susceptible wheat controls (Table 4). Fourteen

Table 4. Multiplication rates and hosting abilities of Pratylenchus spp. for monocotyledonous rangeland and weed plants during 2012

\begin{tabular}{|c|c|c|c|c|c|c|c|c|c|c|}
\hline \multirow[b]{2}{*}{ Plant group } & \multirow[b]{2}{*}{ Common name } & \multirow[b]{2}{*}{ Cultivar } & \multicolumn{4}{|c|}{ P. neglectus } & \multicolumn{4}{|c|}{ P. thornei } \\
\hline & & & BTM $^{w}$ & $P f \pm \mathrm{SE}^{\mathrm{x}}$ & $\mathbf{N}^{\mathbf{y}}$ & $\mathbf{H}^{\mathbf{z}}$ & ВTM & $P f \pm \mathrm{SE}$ & $\mathbf{n}$ & $\mathbf{H}$ \\
\hline Control & Unplanted soil, inoculated & $\ldots$ & $388 \mathrm{e}$ & $0.3 \pm 0.1 \mathrm{~g}$ & 8 & . & $514 \mathrm{e}$ & $0.2 \pm 0.1 \mathrm{~m}$ & 8 & $\ldots$ \\
\hline Control & Susceptible wheat & Louise & $28,287 \mathrm{a}$ & $13.6 \pm 3.2 \mathrm{a}-\mathrm{c}$ & 8 & VG & $47,996 \mathrm{a}$ & $21.9 \pm 2.4 \mathrm{ab}$ & 8 & VG \\
\hline Control & Susceptible wheat & Otis & $34,039 \mathrm{a}$ & $18.8 \pm 3.6 \mathrm{a}$ & 8 & VG & $54,627 \mathrm{a}$ & $21.3 \pm 2.1 \mathrm{a}$ & 8 & VG \\
\hline Range & Beardless wheatgrass & Whitmar & $17,706 \mathrm{ab}$ & $9.9 \pm 2.9 \mathrm{~b}-\mathrm{d}$ & 8 & $\mathrm{G}$ & $19,714 \mathrm{bc}$ & $7.6 \pm 1.2 \mathrm{f}-\mathrm{j}$ & 8 & $\mathrm{G}$ \\
\hline Range & Big bluegrass & Sherman & $26,748 \mathrm{a}$ & $13.4 \pm 4.2 \mathrm{a}-\mathrm{c}$ & 8 & VG & $11,878 \mathrm{c}$ & $4.6 \pm 1.4 \mathrm{~h}-1$ & 8 & M \\
\hline Range & Crested wheatgrass & Fairway & $24,370 \mathrm{a}$ & $13.6 \pm 4.2 \mathrm{a}-\mathrm{c}$ & 8 & VG & $21,675 \mathrm{a}-\mathrm{c}$ & $8.3 \pm 2.3 \mathrm{e}-\mathrm{i}$ & 8 & $\mathrm{G}$ \\
\hline Range & Crested wheatgrass & Hycrest & $29,128 \mathrm{a}$ & $12.7 \pm 2.2 \mathrm{a}-\mathrm{d}$ & 8 & VG & 27,529 a-c & $10.6 \pm 2.5 \mathrm{c}-\mathrm{g}$ & 8 & VG \\
\hline Range & Hard fescue & Durar & $2,411 \mathrm{~cd}$ & $1.4 \pm 0.4 \mathrm{fg}$ & 8 & $\mathrm{M}$ & 24,845 a-c & $9.6 \pm 1.1 \mathrm{e}-\mathrm{i}$ & 8 & $\mathrm{G}$ \\
\hline Range & Intermediate wheatgrass & Greenar & $14,056 \mathrm{ab}$ & $6.5 \pm 1.5 \mathrm{c}-\mathrm{g}$ & 8 & $\mathrm{G}$ & 24,794 a-c & $9.5 \pm 1.7 \mathrm{e}-\mathrm{i}$ & 8 & $\mathrm{G}$ \\
\hline Range & Sheep fescue & Blacksheep & $2,405 \mathrm{~cd}$ & $2.1 \pm 1.0 \mathrm{e}-\mathrm{g}$ & 8 & M & $18,742 \mathrm{bc}$ & $7.2 \pm 1.7 \mathrm{f}-\mathrm{j}$ & 8 & $\mathrm{G}$ \\
\hline Range & Siberian wheatgrass & Vavilov & $5,025 \mathrm{~b}-\mathrm{d}$ & $8.6 \pm 3.2 \mathrm{~b}-\mathrm{f}$ & 8 & $\mathrm{G}$ & 29,640 a-c & $11.4 \pm 3.7 \mathrm{c}-\mathrm{e}$ & 8 & VG \\
\hline Range & Smooth brome & Manchar & 8,616 a-c & $5.1 \pm 1.4 \mathrm{~d}-\mathrm{g}$ & 8 & $\mathrm{G}$ & $16,789 \mathrm{bc}$ & $6.5 \pm 1.1 \mathrm{~g}-\mathrm{k}$ & 8 & $\mathrm{G}$ \\
\hline Range & Snake River wheatgrass & Secar & $11,899 \mathrm{ab}$ & $18.1 \pm 4.4 \mathrm{a}$ & 8 & VG & $41,299 \mathrm{ab}$ & $15.9 \pm 2.5 \mathrm{a}-\mathrm{c}$ & 8 & VG \\
\hline Range & Standard crested wheatgrass & Nordan & $17,287 \mathrm{ab}$ & $9.3 \pm 3.7 \mathrm{~b}-\mathrm{d}$ & 8 & $\mathrm{G}$ & $26,718 \mathrm{a}-\mathrm{c}$ & $10.3 \pm 2.3 \mathrm{c}-\mathrm{h}$ & 8 & VG \\
\hline Range & Tall wheatgrass & Alkar & $9,051 \mathrm{a}-\mathrm{c}$ & $5.2 \pm 1.9 \mathrm{~d}-\mathrm{g}$ & 7 & $\mathrm{G}$ & $3,705 \mathrm{~d}$ & $1.4 \pm 1.2 \mathrm{k}-\mathrm{m}$ & 8 & M \\
\hline Range & Thickspike bluegrass & Critana & $23,686 \mathrm{ab}$ & $13.0 \pm 3.7 \mathrm{a}-\mathrm{c}$ & 8 & VG & $33,082 \mathrm{a}-\mathrm{c}$ & $12.7 \pm 1.6 \mathrm{c}-\mathrm{f}$ & 8 & VG \\
\hline Range & Western wheatgrass & Rosana & $31,382 \mathrm{a}$ & $14.5 \pm 3.0 \mathrm{ab}$ & 8 & VG & $12,396 \mathrm{c}$ & $4.8 \pm 2.9 \mathrm{~d}-\mathrm{i}$ & 8 & M \\
\hline Weed & Downy brome & $\ldots$ & $1,339 \mathrm{de}$ & $2.0 \pm 0.7 \mathrm{e}-\mathrm{g}$ & 8 & $\mathrm{M}$ & $13,583 \mathrm{c}$ & $5.2 \pm 0.6 \mathrm{i}-\mathrm{m}$ & 8 & $\mathrm{G}$ \\
\hline Weed & Green foxtail & $\ldots$ & $21,663 \mathrm{ab}$ & $11.7 \pm 3.5 \mathrm{a}-\mathrm{d}$ & 8 & VG & $2,704 \mathrm{~d}$ & $1.0 \pm 0.5 \mathrm{~lm}$ & 8 & M \\
\hline Weed & Jointed goatgrass & $\ldots$ & $27,498 \mathrm{a}$ & $12.0 \pm 2.2 \mathrm{a}-\mathrm{d}$ & 8 & VG & $41,290 \mathrm{ab}$ & $15.9 \pm 1.2 \mathrm{~b}-\mathrm{d}$ & 8 & VG \\
\hline Weed & Large crabgrass & $\ldots$ & $22,155 \mathrm{ab}$ & $9.2 \pm 1.3 \mathrm{~b}-\mathrm{e}$ & 8 & $\mathrm{G}$ & $2,516 \mathrm{~d}$ & $1.0 \pm 0.1 \mathrm{~m}$ & 8 & $\mathrm{M}$ \\
\hline Weed & Rattail fescue & $\ldots$ & $2,487 \mathrm{~cd}$ & $1.5 \pm 0.4 \mathrm{fg}$ & 8 & M & 29,708 a-c & $11.4 \pm 1.9 \mathrm{c}-\mathrm{g}$ & 8 & VG \\
\hline \multirow[t]{3}{*}{ Weed } & Wild oat & $\ldots$ & $15,505 \mathrm{ab}$ & $8.4 \pm 2.3 \mathrm{~b}-\mathrm{f}$ & 8 & G & $4,239 \mathrm{~d}$ & $1.6 \pm 0.9 \mathrm{j}-\mathrm{m}$ & 8 & M \\
\hline & $P>F$ & & $<0.0001$ & $<0.0001$ & & & $<0.0001$ & $<0.0001$ & & \\
\hline & $\mathrm{CV}(\%)$ & & 17.1 & 82.2 & & & 10.9 & 55.9 & & \\
\hline
\end{tabular}

${ }^{w}$ Final nematode density per kg of soil, expressed as back-transformed means (BTM) from the logarithmic transformations used to normalize the data for ANOVA. Means followed by the same letter did not differ significantly at $P<0.05$ as determined by Least Significant Difference. Assays were over $16-$ week incubation period.

${ }^{x}$ Reproductive factor $(R f)$ and standard error of the mean (SE) calculated as the final nematode density (Pf) divided by the density of Pratylenchus initially added into soil $(\mathrm{Pi}) ; \mathrm{Pi}$ rates were 2,500 P. neglectus $/ \mathrm{kg}$ of soil and 2,594 P. thornei $/ \mathrm{kg}$ of soil.

y Number of observations included in the analysis; $\mathrm{n}<8 /$ year indicates a failure of seedling establishment.

${ }^{\mathrm{z}}$ Hosting ability ratings; $\mathrm{N}=$ nonhost $(R f<0.1), \mathrm{P}=$ poor host $(R f=0.1$ to 0.9$), \mathrm{M}=$ minor host $(R f=1.0$ to 4.9$), \mathrm{G}=$ good host $(R f=5.0$ to 9.9$), \mathrm{VG}=$ very good host $(R f \geq 10.0)$.

Table 5. Multiplication rates and hosting abilities of Pratylenchus spp. for dicotyledonous rangeland and weed plants during 2012

\begin{tabular}{|c|c|c|c|c|c|c|c|c|c|c|}
\hline \multirow[b]{2}{*}{ Plant group } & \multirow[b]{2}{*}{ Common name } & \multirow[b]{2}{*}{ Cultivar } & \multicolumn{4}{|c|}{ P. neglectus } & \multicolumn{4}{|c|}{ P. thornei } \\
\hline & & & BTM $^{w}$ & $P f \pm \mathrm{SE}^{\mathrm{x}}$ & $\mathbf{N}^{\mathbf{y}}$ & $\mathbf{H}^{\mathbf{z}}$ & ВTM & $P f \pm \mathrm{SE}$ & $\mathbf{n}$ & $\mathbf{H}$ \\
\hline Control & Unplanted soil, inoculated & $\ldots$ & $716 \mathrm{fg}$ & $0.3 \pm 0.1 \mathrm{e}$ & 8 & $\ldots$ & $793 \mathrm{fg}$ & $0.4 \pm 0.3 \mathrm{bc}$ & 8 & \\
\hline Control & Susceptible wheat & Louise & $16,008 \mathrm{a}$ & $11.7 \pm 2.3 \mathrm{bc}$ & 8 & VG & $39,426 \mathrm{a}$ & $22.3 \pm 2.1 \mathrm{a}$ & 8 & VG \\
\hline Control & Susceptible wheat & Otis & $62,099 \mathrm{a}$ & $34.2 \pm 2.7 \mathrm{a}$ & 8 & VG & $48,059 \mathrm{a}$ & $26.4 \pm 2.4 \mathrm{a}$ & 8 & VG \\
\hline Range & Alfalfa & Don & $2,646 \mathrm{de}$ & $2.7 \pm 1.6 \mathrm{de}$ & 8 & M & $7,833 \mathrm{~b}$ & $3.9 \pm 2.0 \mathrm{~b}$ & 8 & M \\
\hline Range & Alfalfa & Ladak-65 & $410 \mathrm{~g}$ & $0.2 \pm 0.0 \mathrm{e}$ & 8 & $\mathrm{P}$ & $344 \mathrm{~g}$ & $0.2 \pm 0.0 \mathrm{c}$ & 8 & $\mathrm{P}$ \\
\hline Range & Hairy vetch & Purple Bounty & $12,168 \mathrm{~b}-\mathrm{d}$ & $9.7 \pm 3.7 b-d$ & 8 & G & $3,043 \mathrm{~cd}$ & $1.5 \pm 1.3 \mathrm{bc}$ & 8 & M \\
\hline Range & Hairy vetch & Purple Prosperity & $12,237 \mathrm{~b}-\mathrm{d}$ & $9.1 \pm 3.3 \mathrm{~b}-\mathrm{d}$ & 8 & G & $5,688 \mathrm{bc}$ & $2.8 \pm 1.1 \mathrm{bc}$ & 8 & M \\
\hline Weed & Common lambsquarters & $\ldots$ & 7,209 cd & $3.9 \pm 1.2 \mathrm{c}-\mathrm{e}$ & 7 & M & $1,117 \mathrm{~d}-\mathrm{g}$ & $0.7 \pm 0.3 \mathrm{bc}$ & 2 & $\mathrm{P}$ \\
\hline Weed & Dandelion & $\ldots$ & $795 \mathrm{fg}$ & $0.6 \pm 0.3 \mathrm{de}$ & 8 & $\mathrm{P}$ & $1,161 \mathrm{~d}-\mathrm{f}$ & $0.6 \pm 0.2 \mathrm{bc}$ & 8 & $\mathrm{P}$ \\
\hline Weed & Horseweed & $\ldots$ & $588 \mathrm{fg}$ & $0.3 \pm 0.1 \mathrm{e}$ & 8 & $\mathrm{P}$ & $350 \mathrm{~g}$ & $0.2 \pm 0.1 \mathrm{c}$ & 8 & $\mathrm{P}$ \\
\hline Weed & Kochia & $\ldots$ & $24,875 \mathrm{ab}$ & $13.0 \pm 3.1 \mathrm{~b}$ & 8 & VG & $1,745 \mathrm{de}$ & $0.9 \pm 0.1 \mathrm{bc}$ & 8 & $\mathrm{P}$ \\
\hline Weed & Palmer amaranth & $\ldots$ & 13,483 a-d & $5.9 \mathrm{~b}-\mathrm{e}$ & 1 & $\mathrm{G}$ & $1,342 \mathrm{~d}-\mathrm{f}$ & $0.7 \pm 0.1 b c$ & 3 & $\mathrm{P}$ \\
\hline Weed & Prostrate spurge & $\ldots$ & 1,192 ef & $0.6 \pm 0.1 \mathrm{de}$ & 5 & $\mathrm{P}$ & $1,381 \mathrm{~d}-\mathrm{f}$ & $0.7 \pm 0.2 b c$ & 8 & $\mathrm{P}$ \\
\hline Weed & Redroot pigweed & $\ldots$ & $19,692 \mathrm{ab}$ & $9.4 \pm 2.7 b-d$ & 8 & $\mathrm{G}$ & $1,322 \mathrm{~d}-\mathrm{f}$ & $0.7 \pm 0.1 b c$ & 8 & $\mathrm{P}$ \\
\hline Weed & Russian thistle & $\ldots$ & $4,360 \mathrm{~d}$ & $2.3 \pm 0.5 \mathrm{de}$ & 7 & M & $1,060 \mathrm{e}-\mathrm{g}$ & $0.5 \pm 0.1 \mathrm{c}$ & 7 & $\mathrm{P}$ \\
\hline \multirow[t]{3}{*}{ Weed } & Tumble mustard & $\ldots$ & 13,943 a-c & $8.7 \pm 3.0 \mathrm{~b}-\mathrm{e}$ & 4 & G & $1,043 \mathrm{e}-\mathrm{g}$ & $0.5 \pm 0.1 \mathrm{c}$ & 8 & $\mathrm{P}$ \\
\hline & $P>F$ & & 0.0056 & $<0.0001$ & & & $<0.0001$ & $<0.0001$ & & \\
\hline & $\mathrm{CV}(\%)$ & & 45.4 & 111.4 & & & 9.9 & 101.1 & & \\
\hline
\end{tabular}

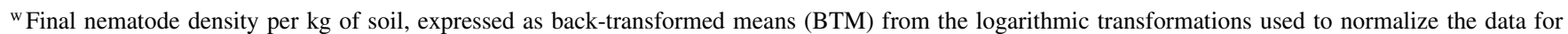
ANOVA. Means followed by the same letter did not differ significantly at $P<0.05$ as determined by Least Significant Difference. Assays were over $12-$ week incubation period.

${ }^{x}$ Reproductive factor $(R f)$ and standard error of the mean (SE) calculated as the final nematode density (Pf) divided by the density of Pratylenchus initially added into soil (Pi); Pi rates were 2,317 P. neglectus/kg of soil and 2,017 P. thornei $/ \mathrm{kg}$ of soil.

y Number of observations included in the analysis; $\mathrm{n}<8 /$ year indicates a failure of seedling establishment.

${ }^{\mathrm{z}}$ Hosting ability ratings; $\mathrm{N}=$ nonhost $(R f<0.1), \mathrm{P}=$ poor host $(R f=0.1$ to 0.9$), \mathrm{M}=$ minor host $(R f=1.0$ to 4.9$), \mathrm{G}=$ good host $(R f=5.0$ to 9.9$), \mathrm{VG}=$ very good host $(R f \geq 10.0)$. 
of those 15 entries differed from the controls using both rating systems; exceptions were that smooth brome 'Manchar' and Siberian wheatgrass 'Vavilov' were similar to the controls with only one of the two rating systems. Sixteen of the 20 monocot entries were categorized as good or very good hosts for $P$. neglectus. For $P$. thornei during 2012, there were 10 and two monocot entries that had log-transformed means or $R f$ values, respectively, that were comparable to at least one of the susceptible wheat controls (Table 4). The two entries that met both comparative criteria were Snake River wheatgrass 'Secar' and jointed goatgrass (Aegilops cylindrica Host). Fourteen entries were categorized as good or very good hosts of $P$. thornei.

For the 13 dicot entries inoculated with $P$. neglectus during 2012 (Table 5), there were four entries with log-transformed means that were statistically similar to the wheat controls. No entries met that standard when the $R f$ value was used for this comparison. Nevertheless, the six entries that were categorized as good to very good hosts of $P$. neglectus included both hairy vetches, kochia (Bassia scoparia (L.) A.J. Scott), palmer amaranth (Amaranthus palmeri S. Watson), redroot pigweed (Amaranthus retroflexus L.), and tumble mustard (Sisymbrium altissimum L.). None of the 13 dicot entries enabled multiplication of $P$. thornei at rates comparable to the wheat controls when using either of the methods of comparison (Table 5). None of the dicot entries were categorized as good or very good hosts of $P$. thornei.

\section{Discussion}

Multiplication rates of $P$. neglectus and $P$. thornei were evaluated in the greenhouse for 18 rangeland plant species and cultivars and 16 weed species. Assays were repeated over 2 years, and hosting abilities were evaluated using two procedures, one based on relative reproductive factor ratios and the other based on final nematode densities compared to two susceptible wheat cultivars. Both systems provided useful insights into the hosting abilities of these Pratylenchus spp., particularly during the second year of assays when plant growth and incubation conditions were more hospitable for the nematodes and for plant growth, as compared to the first year.

Alfalfa and hairy vetch were evaluated because they are components of rainfed conservation plantings in the PNW. However, in areas of higher precipitation or where supplemental irrigation is available, each of these species of Fabaceae is commonly planted as a forage, hay, or green manure crop. In our assays, alfalfa 'Ladak-65' was a poor host and alfalfa 'Don' was a minor host of both Pratylenchus spp. Hairy vetch 'Purple Bounty' and 'Purple Prosperity' were both good hosts of $P$. neglectus and minor hosts of $P$. thornei. Many species and cultivars within the Fabaceae have been reported as hosts of $P$. neglectus and P. thornei (3). Alfalfa and common vetch were reported as hosts of $P$. thornei $(6,14,21)$. Vanstone et al. (50) considered vetch as being susceptible to $P$. thornei and resistant to moderately resistant to P. neglectus. However, Hollaway et al. (14) reported three cultivars of medic and one entry of Persian clover to be resistant to P. thornei. Alfalfa, vetch, and various medics and clovers were also reported as hosts of $P$. neglectus, but much variability in susceptibility occurred among cultivars and in the virulence of $P$. neglectus isolates $(3,10,19,39,40,50)$. Ballard et al. (2) considered eight medic cultivars to be moderately resistant to $P$. neglectus. Townshend and Potter $(44,45)$ reported alfalfa 'Saranac' and 'Vernal' as poor hosts of $P$. neglectus. Our results suggest that densities of $P$. neglectus and $P$. thornei are likely to be increased by modest amounts in conservation plantings that include three of the alfalfa or hairy vetch cultivars we tested. However, these results with individual plant species should be considered conservative in view of reports that multiplication of Pratylenchus spp. may become greater in interplantings than in monostands of legumes and grasses $(7,11,22)$.

Nine of 14 rangeland grasses were good to very good hosts for both $P$. neglectus and $P$. thornei. Three other entries were good hosts for $P$. neglectus but not $P$. thornei, and two entries were good hosts of $P$. thornei but not of $P$. neglectus. None of the 14 entries failed to rate as a good or very good host for at least one of these nematode species. It was clear that many of these grasses are capable of leaving elevated densities of $P$. neglectus and/or P. thornei when conservation plantings are converted to production of an arable crop such as wheat. For example, crested wheatgrass 'Hycrest', Snake River wheatgrass Secar, and thickspike wheatgrass Critana were very good hosts with mean $R f$ values exceeding 10 for both $P$. neglectus and $P$. thornei during the 12-week assays in 2012. Likewise, the $R f$ values exceeded eight for each of these nematodes for crested wheatgrass 'Fairway', Siberian wheatgrass Vavilov, and standard crested wheatgrass 'Nordan'. As a comparison, crested wheatgrass Fairway assayed against three isolates of $P$. neglectus had a range of $R f$ values from 6.9 to 10.3 in a 21-week greenhouse assay that applied comparable rates of inoculum, and $R f$ values ranging from 3.9 to 6.3 in a 20 -week controlled temperature assay using a twofold higher inoculation rate and an incubation temperature comparable to our greenhouse assay (11). Fairway therefore provided a worthy comparison with previous research and confidence that our results during 2012 were within the same range as those published earlier for this cultivar.

We found intermediate wheatgrass 'Greenar', Snake River wheatgrass Secar, crested wheatgrass Fairway and Hycrest, and standard crested wheatgrass Nordan to be good hosts of both Pratylenchus spp. Griffin (7) reported that P. neglectus reduced root dry weights of Secar, Greenar, Fairway, Nordan, and Hycrest by $42,38,32,31$, and $26 \%$, respectively. In this same study (7), the density of $P$. neglectus/g of root at the end of the assay was 25,13 , 12, 11, and 6 for Secar, Greenar, Nordan, Fairway, and Hycrest, respectively. In field trials, Griffin et al. (9) also found that crested wheatgrass Fairway supported higher densities of $P$. neglectus than western wheatgrass Rosana and crested wheatgrass Hycrest during three sampling periods from spring to autumn. The density was greater for Rosana than Hycrest during the spring, and the opposite occurred during the autumn. Similar to our study, Griffin et al. (9) found each of these three species to be good hosts of $P$. neglectus. Townshend and Potter (45) reported that smooth brome 'Saratoga' supported high densities of $P$. neglectus. We also found smooth brome Manchar to be a good host of $P$. neglectus as well as of $P$. thornei. Townshend et al. (43) found hard fescue Durar to be a nonhost of $P$. neglectus, and this cultivar was a minor host of $P$. neglectus but a good host of $P$. thornei in our study. In our assay, sheep fescue Blacksheep was also a minor host of $P$. neglectus but a good host of $P$. thornei. In contrast, big bluegrass 'Sherman', tall wheatgrass 'Alkar', and western wheatgrass Rosana were found to be good hosts of $P$. neglectus and minor hosts of $P$. thornei.

Jointed goatgrass was the only weed that was a very good host for both $P$. neglectus and $P$. thornei. Seven other weeds were good hosts of $P$. neglectus but not of $P$. thornei, including green foxtail, large crabgrass, wild oat, kochia, palmer amaranth, redroot pigweed, and tumble mustard. Downy brome (Bromus tectorum L.) and rattail fescue were good hosts of $P$. thornei but not of $P$. neglectus. Weeds having minor or poor hosting abilities for both nematodes included dandelion (Taraxacum officinale F.H. Wigg.), horseweed (Conyza canadensis (L.) Cronquist), and prostrate spurge (Euphorbia humistrata (Engelm. ex Gray) Small).

The eight weeds determined to be most likely to amplify densities of $P$. neglectus, in order of decreasing hosting ability (based on $R f$ values), were kochia (13.0), jointed goatgrass (12.0), green foxtail (11.7), redroot pigweed (9.4), large crabgrass (9.2), tumble mustard (8.7), wild oat (8.4), and palmer amaranth (5.9). The three weeds most likely to amplify densities of $P$. thornei, in decreasing order, were jointed goatgrass (15.9), rattail fescue (11.4), and downy brome (5.2). Wild oat was also reported as a better host of $P$. neglectus than of $P$. thornei in Australia (51). Likewise, members of the Asteraceae were considered poor hosts of $P$. neglectus and $P$. thornei (52), as was also shown for dandelion and horseweed in our assays. Redroot pigweed and palmer amaranth have been previously reported as hosts of $P$. neglectus (15). Unlike our study, which revealed downy brome as a good host of $P$. thornei and mi- 
nor host of $P$. neglectus, Talavera and Navas (39) found this weed to be an important host of both species and a better host of $P$. neglectus than of $P$. thornei. Owing to the large variation of PNW agricultural ecosystems (26), each of the weeds we tested are present in the inland PNW (54). Susceptible weeds among the Poaceae family occur mostly within planted crops of wheat, and those of other plant families are more prevalent during the fallow period between wheat crops or in broadleaf crops.

Jointed goatgrass is of particular concern because it is a very good host of both P. neglectus and P. thornei and because it is widespread through winter wheat production areas of the PNW (56). This weed and downy brome are largely responsible for the fact that the dominant 'Clearfield' wheat cultivars currently planted in Oregon and Washington are tolerant of imazamox $(47,48)$. These wheat cultivars are sprayed with imazamox herbicide to selectively remove sensitive weeds such as downy brome and jointed goatgrass from the crop (56). It appears likely that when jointed goatgrass is selectively eliminated from imazamox-tolerant winter wheat cultivars, the nematodes will migrate from the dying goatgrass roots and thereby increase the inoculum density available for invading the wheat roots. If so, this phenomenon could be at least partially responsible for observations of winter wheat growth becoming unthrifty, at least temporarily, after imazamox herbicide application (R. W. Smiley, unpublished). This phenomenon, known as the "green bridge", is well known for fungal pathogens (32) and insect pests, and should be investigated for plant-parasitic nematodes such as Pratylenchus spp.

Another common practice in PNW agriculture is to allow winter-annual grass weeds and volunteer wheat plants to persist overwinter after seeds germinate during the autumn. The weeds and volunteers often form a lawn that may persist as long as 6 months (November to April) during the sanitizing phase of the 14-month fallow period between planted winter wheat crops (10-month growing season; September to July). Common winter annual weeds such as jointed goatgrass and rattail fescue were shown in this study to be hosts of one or both Pratylenchus spp. These weeds are potential contributors to the elevated numbers of Pratylenchus spp. observed during the fallow phase of the winter wheat-fallow rotation (29). As reported by Talavera and Navas (39), and based upon local nonquantified observations in the PNW, we previously believed that downy brome also contributed to the elevation of Pratylenchus spp. densities in these cropping systems. That supposition for the PNW was substantiated only for $P$. thornei in our study. Our results with rattail fescue are also important because this weed is particularly well adapted to no-till cropping systems (1) that are becoming increasingly practiced in the PNW (34). We found rattail fescue to be a very good host for $P$. thornei.

Multiplication rates of $P$. neglectus were greater than for $P$. thor$n e i$ on susceptible wheat controls during 2011 when the incubation conditions appeared least favorable to both the nematodes and the plants. In contrast, multiplication rates of $P$. thornei were greater than for P. neglectus for three of four of these controls under more favorable incubation conditions during 2012. The reasons for these apparent relationships are unknown but may relate to differential effects of abiotic conditions on these species. While the same soil was used for all of our assays, it is possible that differences could have occurred for soil moisture, soil temperature, or virulence of the inoculum. Our assay soils were watered by capillarity from the bottom during 2011 and were hand watered from the top during 2012. While the subirrigation system has been effective in our previous assays of wheat $(27,41)$, we made this change in an attempt to improve multiplication rates by assuring that the complete soil column could not become saturated with water during 2012. Also, it is possible that temperatures could have varied slightly during different years. Soil moisture and temperature are known to have differential effects on different Pratylenchus spp. (3), but specific comparisons of these effects on P. neglectus versus $P$. thor$n e i$ are not available. Likewise, it seems likely that inoculum virulence could differ in response to differences in inoculum rearing conditions (carrot cultivar, culture age, proportions of different nematode life stages) and to storage of inoculum suspensions (temperature or time) before dispersal into soil. For instance, Townshend (42) reported that survival of $P$. neglectus in soil was greater for adults and fourth-stage juveniles than for second- and thirdstage juveniles. Effects of moisture and other edaphic conditions on survival and on invasion of roots by various Pratylenchus spp. were reviewed by Castillo and Vovlas (3). While every effort was made to assure uniformity over years, it is possible that minor variations could have occurred in our assays. It is also possible that the greater multiplication rates of $P$. thornei than of $P$. neglectus during 2012 could have been due to an inherently higher reproductive capability of $P$. thornei than of $P$. neglectus under optimal incubation conditions. For instance, we nearly always achieve much higher densities of $P$. thornei than of $P$. neglectus in the carrot cultures used to rear inoculum of these species (G. P. Yan, unpublished data). McKay et al. (16) also stated that when these species occur as mixtures in fields, $P$. thornei tends to dominate because "it has a higher multiplication rate."

Results of these assays provide insights that should be included among considerations for improving the efficiency of rainfed production systems in the PNW. It is likely that reduced efficiency is associated with conversion of rangelands to wheat production systems due in part to elevation of these Pratylenchus spp. in rangeland. Where nematode densities have become elevated in expiring conservation programs, it is suggested that poor or nonhost crop species such as barley, safflower, flax, brown mustard, or selected cultivars of pea or chickpea $(30,37)$ be planted as a transition crop before planting the first crop of wheat. It is also likely that occurrences of specific weeds at any time in the cropping system can elevate densities of Pratylenchus spp. This must become recognized as an important attribute of weed management programs.

\section{Acknowledgments}

This research was funded by a grant from the USDA Cooperative State Research, Extension and Education Service Solutions to Economic and Environmental Problems (STEEP) Pacific Northwest Regional Research Program. Supplemental funding was from the Oregon Agricultural Experiment Station and a United States Department of Agriculture Agricultural Research Service (USDAARS) subcontract to Oregon State University (OSU; SCA number 58-5348-9 100). Seed was provided by Cathy Sawyer (Rainier Seeds, Inc., Davenport, WA) and by Daniel Ball and Richard Smiley (OSU, Pendleton), Donn Thill (University of Idaho, Moscow), and Mike Peel (USDA-ARS, Logan, UT). We also appreciated technical assistance by Mike Baxter, Cameron Dumont, Alysha Hitzman, Stephen Isbell, Paul Thorgersen, and Nick Webster.

\section{Literature Cited}

1. Ball, D. A., and Hulting, A. G. 2009. Rattail fescue: Biology and management in Pacific Northwest wheat cropping systems. Pacific Northwest Ext. Bull. PNW 613. Oregon State University, Corvallis, OR.

2. Ballard, R. A., Hutton, R. E., Taylor, S. P., McKay, A. C., and Howie, J. H 2006. Field resistance of annual pasture legumes to the root lesion nematode, Pratylenchus neglectus. Australas. Plant Pathol. 35:303-308.

3. Castillo, P., and Vovlas, N. 2007. Pratylenchus, Nematoda, Pratylenchidae: Diagnosis, biology, pathogenicity and management. Nematol. Monogr. Perspect. 6:1-530.

4. Fatemy, S., Abootorabi, E., Ebrahimi, N., and Aghabeigi, F. 2006. First report of Pratylenchus neglectus and P. thornei infecting canola and weeds in Iran. Plant Dis. 90:1555.

5. Ferris, H. L., Carlson, D. R., Viglierchio, D. R., Westerdahl, B. B., Wu, F. W., Anderson, C. E., Juurma, A., and Kirby, D. W. 1993. Host status of selected crops to Meloidogyne chitwoodi. J. Nematol. 25(4S):849-857.

6. Greco, N., Di Vito, M., Saxena, M. C., and Reddy, M. V. 1988. Investigation on the root lesion nematode Pratylenchus thornei, in Syria. Nematol. Mediterr. 16:101-105.

7. Griffin, G. D. 1992. Pathological effects of Pratylenchus neglectus on wheatgrasses. J. Nematol. 24:442-449.

8. Griffin, G. D. 1994. Effect of single and interplantings on pathogenicity of Pratylenchus penetrans and $P$. neglectus to alfalfa and crested wheatgrass. J. Nematol. 26:460-466.

9. Griffin, G. D., Asay, K. H., and Horton, W. H. 1996. Factors affecting population trends of plant-parasitic nematodes on rangeland grasses. J. Nematol. 28:107-114.

10. Griffin, G. D., and Gray, F. A. 1990. The biology and pathogenicity of Pratylenchus neglectus on alfalfa. J. Nematol. 22:546-551.

11. Griffin, G. D., and Jensen, K. B. 1997. Differential effects of Pratylenchus neglectus populations on single and interplantings of alfalfa and crested wheatgrass. J. Nematol. 29:82-89. 
12. Hafez, S. I., Golden, A. M., Rashid, R., and Handoo, Z. 1992. Plant-parasitic nematodes associated with crops in Idaho and eastern Oregon. Nematropica 22:193-204.

13. Handoo, Z. A., and Golden, A. M. 1989. A key and diagnostic compendium to the species of the genus Pratylenchus Filipjev, 1936 (lesion nematodes). J. Nematol. 21:202-218.

14. Hollaway, G. J., Taylor, S. P., Eastwood, R. F., and Hunt, C. H. 2000. Effect of field crops on density of Pratylenchus in southeastern Australia: P. thornei. J. Nematol. 32(4S):600-608.

15. Kornobis, S., and Wolny, S. 1997. Occurrence of plant parasitic nematodes on weeds in agrobiocenosis in the Wielkopolska region in Poland. Fund. Appl. Nematol. 20:627-632.

16. McKay, A., Roget, D., Hannam, R., and Ophel Keller, K., eds. 2008. Root Disease Risk Management Resource Manual. South Australian Research and Development Institute, Glen Osmond, SA.

17. Mojtahedi, H., Santo, G. S., and Ingham, R. E. 1993. Suppression of Meloidogyne chitwoodi populations with selected sudangrass and sorghum-sudangrass cultivars as green manure. J. Nematol. 25:303-311.

18. Moody, E. H., Lownsbery, B. F., and Ahmed, J. M. 1973. Culture of the root-lesion nematode Pratylenchus vulnus on carrot disks. J. Nematol. 19:125-134.

19. Nelson, D. L., Barnes, D. K., and MacDonald, D. H. 1985. Field and growth chamber evaluations for root-lesion nematode resistance in alfalfa. Crop Sci. 25:35-39

20. Oostenbrink, M. 1966. Major characteristics of the relation between nematodes and plants. Meded. Landbo. Wageningen 66:3-46.

21. Orion, D., Krikun, J., and Sullami, M. 1979. The distribution, pathogenicity and ecology of Pratylenchus thornei in the northern Negev. Phytoparasitica 7:3-9.

22. Petersen, A. D., Barnes, D. K., and Thies, J. A. 1991. Preference of rootlesion nematode for alfalfa and forage grasses growing in binary mixtures. Crop Sci. 31:567-570.

23. Potter, J. W., and Townshend, J. L. 1973. Distribution of plant-parasitic nematodes in field crop soils of southwestern and central Ontario. Can. Plant Dis. Surv. 53:39-48.

24. Proctor, J. R., and Marks, C. F. 1974. The determination of normalising transformations for nematode count data from soil samples and of efficient sampling schemes. Nematologica 20: 395-406.

25. Santo, G. S., Evans, D. W., and Bower, D. B. 1980. Reactions of three alfalfa cultivars to several species of plant-parasitic nematodes. Plant Dis. 64:404-405.

26. Schillinger, W. F., Papendick, R. I., Guy, S. O., Rasmussen, P. E., and Van Kessel, C. 2006. Dryland cropping in the western United States. Pages 365393 in: Dryland Agriculture, 2nd ed. G. A. Peterson, P. W. Unger, and W. A. Payne, eds. Agron. Monogr. 23, American Society of Agronomy, Madison, WI.

27. Sheedy, J. G., Raupp, W. J., Thompson, A. L., and Smiley, R. W. 2008. Resistance to root lesion nematodes of Chinese Spring $\times$ Aegilops speltoides addition lines; Pratylenchus neglectus and P. thornei. Plant Dis. Manag. Rep. 2:N038.

28. Smiley, R. W. 2010. Root-lesion nematodes reduce yield of intolerant wheat and barley. Agron. J. 101:1322-1335.

29. Smiley, R. W., and Machado, S. 2009. Pratylenchus neglectus reduces yield of winter wheat in dryland cropping systems. Plant Dis. 93:263-271.

30. Smiley, R. W., Machado, S., Gourlie, J. A., Pritchett, L. C., Yan, G. P., and Jacobsen, E. E. 2013. Effects of crop rotation and tillage on Pratylenchus species in the semi-arid Pacific Northwest USA. Plant Dis. 97:537-546.

31. Smiley, R. W., Merrifield, K., Patterson, L.-M., Whittaker, R. G., Gourlie, J. A., and Easley, S. A. 2004. Nematodes in dryland field crops in the semiarid Pacific Northwest USA. J. Nematol. 36:54-68.

32. Smiley, R. W., Ogg, A. G., Jr., and Cook, R. J. 1992. Influence of glyphosate on Rhizoctonia root rot, growth, and yield of barley. Plant Dis. 76:937942

33. Smiley, R. W., Sheedy, J. G., and Easley, S. A. 2008. Vertical distribution of Pratylenchus spp. in silt loam soil of Pacific Northwest dryland crops. Plant Dis. 92:1662-1668

34. Smiley, R. W., Siemens, M., Golke, T., and Poore, J. 2005. Small grain acreage and management trends for eastern Oregon and Washington. Ore- gon State Univ. Agric. Exp. Stn. Spec. Rep. 1061:30-50.

35. Smiley, R. W., Whittaker, R. G., Gourlie, J. A., and Easley, S. A. 2005. Pratylenchus thornei associated with reduced wheat yield in Oregon. J. Nematol. 37:45-54.

36. Smiley, R. W., Whittaker, R. G., Gourlie, J. A., and Easley, S. A. 2005 Suppression of wheat growth and yield by Pratylenchus neglectus in the $\mathrm{Pa}$ cific Northwest. Plant Dis. 89:958-968.

37. Smiley, R. W., Yan, G. P., and Gourlie, J. A. 2014. Selected Pacific Northwest crops as hosts of Pratylenchus neglectus and P. thornei. Plant Dis. 98:1341-1348.

38. Strausbaugh, C. A., Bradley, C. A., Koehn, A. C., and Forster, R. L. 2004 Survey of root diseases of wheat and barley in southeastern Idaho. Can. J. Plant Pathol. 26:167-176.

39. Talavera, M., and Navas, A. 2002. Incidence of plant-parasitic nematodes in natural and semi-natural mountain grassland and the host status of some common grass species. Nematology 4:541-552.

40. Taylor, S. P., Hollaway, G. J., and Hunt, C. H. 2000. Effect of field crops on population densities of Pratylenchus neglectus and P. thornei in southeastern Australia: P. neglectus. J. Nematol. 32:591-599.

41. Thompson, A. L., Sheedy, J. G., Campbell, K. G., Okubara, P. A., and Smiley, R. W. 2008. Resistance of wheat to the root lesion nematode; Pratylenchus thornei. Plant Dis. Manag. Rep. 2:N039.

42. Townshend, J. L. 1973. Survival of Pratylenchus penetrans and P. minyus in two Ontario soils. Nematologica 19:35-42.

43. Townshend, J. L., Eggens, J. L., and McCollum, N. K. 1973. Turf grass hosts of three species of nematodes associated with forage crops. Can. Plant Dis. Surv. 53:137-141.

44. Townshend, J. L., and Potter, J. W. 1973. Nematode numbers under cultivars of forage legumes and grasses. Can. Plant Dis. Surv. 53:194-195.

45. Townshend, J. L., and Potter, J. W. 1976. Evaluation of forage legumes, grasses, and cereals as hosts of forage nematodes. Nematologica 22:196-201.

46. U.S. Dep. Agric., Farm Service Agency. 2013. Conservation Reserve Program Monthly Summary (June 2013). http://www.fsa.usda.gov/Internet/ FSA_File/june2013crpstat.pdf. Accessed April 1, 2014.

47. U.S. Dep. Agric., National Agricultural Statistics Service. 2011. Oregon Wheat Varieties (July 2011). www.nass.usda.gov/Statistics_by_State/ Oregon/Publications/Field_Crop_Report/wheat and barley variety/wv7_12. pdf. Accessed April 1, 2014

48. U.S. Dep. Agric., National Agricultural Statistics Service. 2011. Washington Wheat Variety (July 2011). http://www.nass.usda.gov/Statistics by_State/ Washington/Publications/Small_Grains/whtvar11.pdf. Accessed April 1, 2014.

49. U.S. Dep. Agric., Natural Resources and Conservation Service. 2000. Oregon \& Washington Guide for Conservation Seedings and Plantings (April 2000). ftp://ftp-fc.sc.egov.usda.gov/OR/Plants-Materials/OR\%20WA\%20 seeding\%20guide.pdf. Accessed April 1, 2014.

50. Vanstone, V. A., Hollaway, G. J., and Stirling, G. R. 2008. Managing nematode pests in the southern and western regions of the Australian cereal industry: Continuing progress in a challenging environment. Australas. Plant Pathol. 37:220-234.

51. Vanstone, V. A., and Russ, M. H. 2001. Ability of weeds to host the roo lesion nematodes Pratylenchus neglectus and P. thornei: I. Grass weeds. Australas. Plant Pathol. 30:245-250.

52. Vanstone, V. A., and Russ, M. H. 2001. Ability of weeds to host the root lesion nematodes Pratylenchus neglectus and P. thornei: II. Broad-leaf weeds. Australas. Plant Pathol. 30:251-258.

53. Whitehead, A. G., and Hemming, J. R. 1965. A comparison of some quantitative methods of extracting small vermiform nematodes from soil. Ann. Appl. Biol. 55:25-38.

54. Whitson, T. D., ed. 2009. Weeds of the West, 10th ed. Western Soc. Weed Sci., Las Cruces, NM.

55. Yan, G. P., Smiley, R. W., Okubara, P. A., Skantar, A., Easley, S. A., Sheedy, J. G., and Thompson, A. L. 2008. Detection and discrimination of Pratylenchus neglectus and $P$. thornei in DNA extracts from soil. Plant Dis 92:1480-1487.

56. Yenish, J. P., Ball, D. A., and Schirman, R. 2009. Integrated management of jointed goatgrass in the Pacific Northwest. Washington State Univ. Ext. Bull. EB2042. Pullman, WA. 